Agro-Science Journal of Tropical Agriculture, Food, Environment and Extension Volume 20 Number 1 (January 2021) pp. 38 - 45

ISSN 1119-7455

\title{
GROWTH RESPONSE AND FEED UTILIZATION IN Clarias gariepinus FINGERLINGS FED DIETS SUPPLEMENTED WITH PROCESSED FLAMBOYANT (Delonix regia) LEAF MEAL
}

\author{
*Adesina S.A. and Agbatan O.D. \\ Department of Fisheries \& Aquaculture Technology, Faculty of Agriculture, Food \& Natural Resources, \\ Ondo State University of Science \& Technology, Okiti-Pupa, Nigeria \\ *Corresponding author’s email: adesinasimon@yahoo.com
}

\begin{abstract}
Expanding utilization of conventional fish feed ingredients by man and fish feed industries has necessitated consideration of cheaper and locally available alternatives. A 70-day feeding trial was conducted to assess the effect of substituting graded levels of sundried flamboyant (Delonix regia) leaf meal (SFLM) for groundnut cake on growth and feed utilization of 240 Clarias gariepinus fingerlings at six substitution levels of 0 (control), $20,40,60,80$ and $100 \%$ in 12 plastic aquaria $(50 \times 40 \times 40 \mathrm{~cm})$. Each dietary treatment was randomly assigned in two replicates each to the aquaria making 12 treatment units and each aquarium had 20 fish. SFLMsupplemented diets and fish carcass were proximately analyzed using standard procedures. Mean weight gain $(M W G)$, specific growth rate (SGR) and feed conversion ratio (FCR) were determined. Data obtained were analyzed using descriptive statistics and ANOVA at $p \leq 0.05$. Crude protein was highest (68.89\%) in fish fed with diet 4, least $(64.61 \%)$ in fish fed with diet 1 (control) and significantly $(p<0.05)$ exceeded $60.54 \%$ of the pre-treatment fish carcass. Fish fed with diet 3 had significantly $(p<0.05)$ higher values of MWG $(11.73 \mathrm{~g})$, SGR (2.13\%/day) and superior FCR (0.451) above which growth and feed utilization indices progressively declined with increase in the substitution level of SFLM. This study revealed that $40 \%$ substitution level of the SFLM resulted in the best growth and feed utilization in C. gariepinus. The study demonstrated the considerable potential of flamboyant leaf meal as an alternative protein source, therefore other processing methods are recommended to increase its utilization, reduce feed cost and maximize aquaculture profitability.
\end{abstract}

Key words: flamboyant leaf meal, Clarias gariepinus, nutrition, survival, growth performance

\section{INTRODUCTION}

As the need to improve and sustain human food security particularly among economically challenged developing countries is highly imperative, aquaculture has been identified as an increasingly suitable option for improving animal protein intake from 40 to about $60 \%$ in order to achieve expected sustainable development goal (Afe and Omosowone, 2019). This target can only be feasible through identification and utilization of high-quality feedstuffs which are rich in protein and other essential nutrients in a bid to improving growth without compromising the animal's general wellbeing (Soltan and El-Laithy, 2008). Efforts to sustain the consistent global growth of aquaculture industry have necessitated a corresponding increase in high-quality fish feed production (Francis et al., 2001). The cost of feed production alone accounts for $40-65 \%$ of total operating costs of finfish aquaculture production in Africa, hence the search for cheap and locally available alternative feed ingredients (Bake et al., 2014). Protein is the most important nutrient and expensive component of fish feed and protein sources usually constitute about $60 \%$ or more in the cost of aqua feed production. According to Tacon (1993), fishmeal has been the most conventionally preferred dietary protein source for many farmed fish and is cherished for its balanced amino acid profile, vitamin content, palatability and unknown growth factors. However, Bake et al. (2014) reported that inadequate supply, rising demand and high cost of fishmeal are among several challenges facing the sustainable development of aquaculture industry, hence the need to attempt broader utilization of cheaper protein-rich ingredients from plant and animal sources for the production of costeffective and eco-friendly fish feeds. Besides, there has been significant emphasis on the utilization of conventional plant protein sources which include soybean seeds (Koumi et al., 2009), groundnut seeds (Ovie and Ovie, 2007), cotton seeds (ElSaidy and Gaber, 2004) and rapeseed meal (Burel et al., 2000). However, the increasing scarcity of these protein sources and competitive demand from other sectors for human use, livestock consumption and industrial purposes continue to heighten their costs far beyond the reach of most fish farmers and fish feed manufacturers (Fasakin et al., 1999).

Please cite as: Adesina S.A. and Agbatan O.D. (2021). Growth response and feed utilization in Clarias gariepinus fingerlings fed diets supplemented with processed flamboyant (Delonix regia) leaf meal. Agro-Science, 20 (1), 38-45. DOI: https://dx.doi.org/10.4314/as.v20i1.7 
Therefore, in order to achieve a more economically sustainable, environmentally friendly and viable fish feed production, research efforts have been geared towards possible consideration and utilization of unconventional sources of protein, particularly those from plants and their by-products such as fruits, seeds, leaves as well as other important agro-allied by-products (Ali et al., 2003; Bake et al., 2009).

Flamboyant (Delonix regia), a leguminous plant belonging to the bean family Fabaceae (Subfamily Caesalpinioideae; Order Fabales), is a wild, beautiful and semi-deciduous tree otherwise known as flame-of-the-forest which originated from Madagascar but is now found wild or grown as an ornamental tree in Nigeria and many parts of the globe (Purseglove, 1994). It can be easily propagated from seeds but takes a long time to germinate. It grows to $12-15 \mathrm{~m}$ with its elegant slightly flat or curved wide-spreading umbrella-like crown/canopy sometimes tending to be wider than its height. Its leaflets are less than $12 \mathrm{~mm}$ long, opposite in arrangement and are borne on long stalks. Its flowering is spontaneous and usually produces conspicuous scarlet, red or sometimes paler orange-red flowers, being regarded as one of the most spectacular flowering trees of the tropics (Bake et al., 2014). During its fruiting season, it produces numerous $25-40 \mathrm{~cm}$ long pods/fruits which dangle from the branches, are green and flaccid when young and later turn dark brown or black and hard when mature (Grant et al., 1991). On ripening, the mature dry fruit or pod splits open by explosive mechanism into two halves to release the 7-10 elongated hard seeds. Previous studies reported on the use of parts of flamboyant tree in fish nutrition included boiled flamboyant seed meal and Nile tilapia (Oreochromis niloticus) fingerlings (Balogun et al., 2004), toasted and cooked flamboyant seed meal and $O$. niloticus fingerlings (Bake et al., 2013; 2014) as well as raw, fermented and cooked flamboyant seed meal and Heterobranchus bidorsalis fingerlings (Oyegbile et al., 2017). However, there is a dearth of information on the utilization of flamboyant leaves as a dietary protein ingredient in fish feed formulation. Therefore, this study was conducted to assess the suitability and effect of incorporating sundried flamboyant leaf meal in the formulated diet of Clarias gariepinus fingerlings through their growth response and feed utilization.

\section{MATERIALS AND METHODS}

Experimental Diet Formulation and Preparation Eight kilograms of fresh leaves of flamboyant (Delonix regia) tree were collected within the campus of Ondo State University of Science and Technology, Okitipupa and taken to the Department of Biological Sciences where they were identified and authenticated by a plant taxonomist. The leaves were sundried for five days and ground into a powdery form using a locallyfabricated grinder. Six iso-nitrogenous $(40 \%$ crude protein) experimental diets were formulated from commercial ingredients using Pearson's square method (Table 1). Sundried flamboyant leaf meal (SFLM) was substituted for groundnut cake at varied levels of 0 (control diet), 20, 40, 60, 80 and $100 \%$ in the diets and were designated as $0 \%$ SFLM (Diet 1), 20\% SFLM (Diet 2), 40\% SFLM (Diet 3), 60\% SFLM (Diet 4), 80\% SFLM (Diet 5) and $100 \%$ SFLM (Diet 6) respectively. The diets were separately prepared by thoroughly mixing the dry ingredients inside a Hobart A-2007 mixer (Hobart Ltd, London, UK) after which palm oil and warm water (at a proportion of $1: 2$, that is, water to dry diet mixture) were added to the dry mixture to produce a homogenous paste. Each of the separately mixed diet pastes was steam-pelleted through a 2mm die Hobart pelletizer (A-2007 Model, Hobart $\mathrm{Ltd}$, London, UK). The pellets were dried at $50^{\circ} \mathrm{C}$ for $48 \mathrm{~h}$ in an electric oven (Fan Azma Gostar, BM 55 Model), cooled to room temperature and stored in separate airtight containers prior to use.

\section{Experimental Procedure and Fish Feeding Trial} The ten-week feeding trial was conducted in the Fish Nutrition Research Laboratory of Fisheries and Aquaculture Unit, Department of Biological Sciences, Ondo State University of Science and Technology, Okitipupa, Nigeria. A total of $280 C$. gariepinus fingerlings (initial body weight: $5.11 \pm 0.01 \mathrm{~g}$ ) were purchased from a reputable local commercial hatchery in Okitipupa, Ondo State. Prior to the feeding trial, the fingerlings were acclimatized to the experimental conditions in four separate plastic tanks with dimension $1 \mathrm{~m} \times 1 \mathrm{~m} \times$ $0.5 \mathrm{~m}$ for 7 days and fed twice daily with $2 \mathrm{~mm}$ Coppens commercial feed to visual satiation. At the start of the experiment, 240 closely-sized fingerlings (initial body weight: $5.11 \pm 0.01 \mathrm{~g}$ ) were batchweighed using a sensitive weighing balance (OHAUS LS, Model 2000) and randomly distributed into 12 plastic aquaria $(50 \times 40 \times 40 \mathrm{~cm})$ at 20 fish per aquarium containing 20 litres of water each. Using completely randomized design, six dietary treatments were randomly assigned in two replicates each to the experimental aquaria making twelve treatment units. Fish were manually fed twice daily $(07: 00$ and 17:00 h) at $5 \%$ of their body weight administered in two equal portions with continuous aeration in each aquarium through an air-stone connected to a central UPETTOOLS aquarium air pump (HD202 New 4W-2 Outlets, manufactured by UPETTOOLS Company, Amazon, USA). Temperature of the water culture medium in the aquaria was measured using mercury-in-glass thermometer, dissolved oxygen values measured using Hydrolab Model "Multi 340I/SET" while pH values were determined by means of pH meter (Jenway 3015 pH meter). 
Table 1: Ingredient composition ( $\mathrm{g} / 100 \mathrm{~g}$ diet) of experimental diets containing graded levels of sundried flamboyant leaf meal

\begin{tabular}{|c|c|c|c|c|c|c|}
\hline \multirow[b]{2}{*}{ Dietary ingredients } & \multicolumn{6}{|c|}{ Dietary treatments } \\
\hline & $\begin{array}{c}\text { Diet } 1 \\
0 \% \text { SFLM } \\
\text { (control) }\end{array}$ & $\begin{array}{c}\text { Diet } 2 \\
20 \% \text { SFLM }\end{array}$ & $\begin{array}{c}\text { Diet } 3 \\
40 \% \text { SFLM }\end{array}$ & $\begin{array}{c}\text { Diet } 4 \\
60 \% \text { SFLM }\end{array}$ & $\begin{array}{c}\text { Diet } 5 \\
80 \% \text { SFLM }\end{array}$ & $\begin{array}{c}\text { Diet } 6 \\
100 \% \text { SFLM }\end{array}$ \\
\hline Fishmeal & 20.47 & 20.47 & 20.47 & 20.47 & 20.47 & 20.47 \\
\hline Soybean meal & 20.47 & 20.47 & 20.47 & 20.47 & 20.47 & 20.47 \\
\hline Groundnut cake & 40.94 & 32.75 & 24.56 & 16.38 & 8.19 & ------- \\
\hline Flamboyant leaf meal & ------- & 8.19 & 16.38 & 24.56 & 32.75 & 40.94 \\
\hline Yellow maize & 10.14 & 10.14 & 10.14 & 10.14 & 10.14 & 10.14 \\
\hline Bone meal & 2.00 & 2.00 & 2.00 & 2.00 & 2.00 & 2.00 \\
\hline Vitamin premix & 1.50 & 1.50 & 1.50 & 1.50 & 1.50 & 1.50 \\
\hline Palm oil & 1.00 & 1.00 & 1.00 & 1.00 & 1.00 & 1.00 \\
\hline Salt & 1.00 & 1.00 & 1.00 & 1.00 & 1.00 & 1.00 \\
\hline Starch & 2.50 & 2.50 & 2.50 & 2.50 & 2.50 & 2.50 \\
\hline Total (g) & 100.00 & 100.00 & 100.00 & 100.00 & 100.00 & 100.00 \\
\hline $\begin{array}{l}\text { SFLM - sundried flam } \\
250 \mathrm{mg} \text {; Vit. } \mathrm{B}_{2}: 1750 \\
\text { Calcium D-pantothena } \\
\text { Selenium }\left(\mathrm{Na}_{2} \mathrm{SeO}_{3} .5 \mathrm{H}\right. \\
\text { Producer: DSM Nutriti }\end{array}$ & $\begin{array}{l}\text { leaf meal; } \\
\text { it. } \mathrm{B}_{6}: 875 \mathrm{r} \\
0 \mathrm{mg} \text {; Nico } \\
5 \mathrm{mg} \text {; Iodin } \\
\text { oducts Eurc }\end{array}$ & $\begin{array}{l}\text { ilogram of } \\
\text { B }_{12}: 2500 \mathrm{n} \\
\text { id: } 3750 \mathrm{mg} \\
\text { ssium iodide } \\
\text { ited. Basle }\end{array}$ & $\begin{array}{l}\text { nineral prem } \\
\text { C: } 12,500 \mathrm{~m} \\
\text { cid: } 250 \mathrm{mg} \text {; } \\
\text { g; Anti-oxids }\end{array}$ & $\begin{array}{l}\text { ined the foll } \\
{ }_{3}: 600,000 \mathrm{I} \\
24,999 \mathrm{mg} \\
\mathrm{mg} \text {. }\end{array}$ & $\begin{array}{l}\text { Vit. A: } 1,00 \\
\text { t. E: } 12,000 \\
\text { per: } 1999 \mathrm{mg}\end{array}$ & $\begin{array}{l}0 \mathrm{IU} \text {; Vit. } \mathrm{B}_{1} \text { : } \\
\text { it. } \mathrm{K}_{3}: 15 \mathrm{mg} \text {; } 11,249 \mathrm{mg} \text {; }\end{array}$ \\
\hline
\end{tabular}

\section{Determination of Proximate Analyses of Experimental Diets and Fish Carcass}

Eight grams each of the diet and sun-dried flamboyant leaf meal, six pre-treatment fish specimens and four post-treatment fish specimens per treatment were randomly collected and kept frozen to determine the proximate composition of experimental diets and fish carcass. Dry matter (at $105^{\circ} \mathrm{C}$ for $24 \mathrm{~h}$ ), crude protein (nitrogen $\times 6.25$, using Kjeldahl apparatus), crude lipid (extracted with petroleum ether by Soxhlet apparatus), total ash (by incineration at $600^{\circ} \mathrm{C}$ for $6 \mathrm{~h}$ in a Gallenkamp blast furnace chamber, Gallenkamp, UK), moisture content (by oven-drying to a constant weight in a Gallenkamp oven) and nitrogen-free extract (by subtracting other values from $100 \%$ ) were analyzed according to the standard methods of AOAC (2011). The analyses were conducted in the Department of Animal Production \& Health, Federal University of Technology, Akure, Nigeria. Proximate composition of ingredients used in the experimental diets is presented in Table 2.

\section{Biological Assessment of Fish Growth and Feed Utilization Indices}

Growth and feed utilization indices of the fish were calculated as follows:

i. Mean weight gain $(M W G)=\left(W_{2}-W_{l}\right) g$ (Iheanacho et al., 2017); where $W_{l}$ is initial mean weight $(\mathrm{g})$, and $W_{2}$ is final mean weight (g).

ii. Percentage weight gain $(\%)=$ $\frac{\text { Mean weight gain }(g) \times 100}{\text { Initial mean weight }(g)}$ (Adesina and Ikuyeju, 2019)

iii. Feed intake $(\boldsymbol{g})=\mathrm{WFI}_{1}+\mathrm{WFI}_{2}+\mathrm{WFI}_{3}+\ldots$ $\mathrm{WFI}_{\mathrm{n}}$; where WFI is weekly feed intake of fish per treatment $(\mathrm{g})$, and $1,2,3, \ldots n$ represent first week to the last week of the experimental duration.

iv. Feed conversion ratio $(F C R)=$ $\frac{\text { Mean feed intake }(g)}{\text { Mean weight gain }(g)} \quad$ (Adesina and Ikuyeju, 2019) v. Specific growth rate $\left(\frac{\%}{\text { day }}\right)=$ $\frac{(\text { Ln Wf }- \text { Ln Wi }) \times 100}{t(\text { days })}$ (Adesina and Ikuyeju, 2019); where $\mathrm{Ln} \mathrm{W}_{\mathrm{f}}$ is natural logarithm of the fish final weight; $\mathrm{Ln} \mathrm{W}_{\mathrm{i}}$ is natural logarithm of the fish initial weight; and $t$ is experimental duration in days.

vi.

$$
\begin{aligned}
& \text { Protein intake }\left(g \text { of protein in } 100 g \frac{\text { diet }}{\text { fish }}\right) \\
& =\frac{\text { feed intake } \times \% \text { crude protein in diet }}{100}
\end{aligned}
$$

(Adesina and Ikuyeju, 2019)

vii. Protein efficiency ratio $(P E R)=$ Mean weight gain

Mean protein intake (g of protein in $100 \mathrm{~g}$ of diet/fish)

(Adesina and Ikuyeju, 2019)

viii. Nitrogen metabolism $(N M)=$ $\frac{0.549 \times(W i+W f) t}{2} \quad$ (Nwanna, 2003); where $\mathrm{W}_{\mathrm{i}}$ is initial mean weight of fish; $\mathrm{W}_{\mathrm{f}}$ is final mean weight of fish; $t$ is experimental period in days; and 0.549 is metabolism factor.

\section{ix. Percentage survival, $P S(\%)=$ Final number of fish harvested $\times 100$ \\ Initial number of fish stocked}

(Adesina and Ikuyeju, 2019)

\section{Statistical Analysis}

Data obtained on the effects of substituting sundried flamboyant leaf meal for groundnut cake on growth, feed utilization and body composition of $C$. gariepinus fingerlings were subjected to oneway analysis of variance (ANOVA) using SPSS software (Statistical Package for Social Sciences, 22.0 version). Data were presented as means of replicate values \pm standard deviation. Effects of treatments were considered as being significant at $p<0.05$. Significant $(p<0.05)$ differences among means were compared and separated using Tukey's multiple range test (Zar, 1996). 


\section{RESULTS}

Proximate Composition of Test Ingredient and Experimental Diets

Table 2 shows the proximate composition of sundried flamboyant leaf meal and other ingredients used in the experimental diets. Proximate analysis showed that flamboyant leaf meal had high levels of crude protein and nitrogenfree extract. The result of experimental diets is shown in Table 3. There was no significant difference $(p>0.05)$ in the crude protein values of the experimental diets. However, values of the crude lipid, total ash, crude fibre, moisture and nitrogen-free extract contents in the experimental diets showed significant difference $(p<0.05)$.

Body Composition of $C$. gariepinus Fingerlings Fed Flamboyant Leaf Meal-Based Diets

Chemical composition of experimental fish carcass

(Table 4) followed an irregular pattern and exhibited significant $(p<0.05)$ variations among the treated fish, hence indicating that inclusion of sundried flamboyant leaf meal affected body composition of experimental fish. Crude protein values in the experimental fish carcasses were significantly different $(p<0.05)$ from the values of the pretreatment fish carcass. Likewise, the values of the crude lipid, total ash, nitrogen-free extract and moisture contents observed in the experimental fish carcass showed significant difference $(p<0.05)$.

\section{Physico-Chemical Parameters of Fish Culture Water in Experimental Aquaria}

Table 5 shows the results of the physico-chemical parameters of water quality recorded in the experimental units throughout the experimental duration which were not significantly different $(p>0.05)$ among all treatments. Dissolved oxygen varied from 5.84 to $6.39 \mathrm{mg} \mathrm{l}^{-1}$, temperature from 26.49 to $27.53^{\circ} \mathrm{C}$ and $\mathrm{pH}$ from 7.59 to 7.83 .

Table 2: Proximate composition (\%) of dietary ingredients used in this study

\begin{tabular}{|c|c|c|c|c|c|}
\hline $\begin{array}{l}\text { Proximate } \\
\text { parameters }\end{array}$ & Fish meal & Soybean meal & Groundnut cake & $\begin{array}{c}\text { Sundried flamboyant } \\
\text { leaf meal }\end{array}$ & Corn meal \\
\hline Crude protein & 70.36 & 45.12 & 44.12 & 24.72 & 9.86 \\
\hline Crude lipid & 10.53 & 10.15 & 9.72 & 5.61 & 3.25 \\
\hline Crude fibre & -------- & 6.23 & 8.25 & 10.20 & 20.57 \\
\hline Total ash & 9.65 & 7.52 & 8.53 & 8.94 & 7.68 \\
\hline Moisture & 9.46 & 9.76 & 10.63 & 9.67 & 11.01 \\
\hline Nitrogen-free extract & ---- & 21.22 & 18.75 & 40.86 & 47.63 \\
\hline
\end{tabular}

Table 3: Proximate composition of sundried flamboyant leaf meal-based experimental diets fed to C. gariepinus fingerlings

\begin{tabular}{|c|c|c|c|c|c|c|}
\hline Proximate parameters & Diet1 (Control) & Diet 2 & Diet 3 & Diet 4 & Diet 5 & Diet 6 \\
\hline Ash (\%) & $11.56 \pm 0.11^{\mathrm{b}}$ & $11.69 \pm 0.02^{\mathrm{b}}$ & $11.74 \pm 0.23^{\mathrm{b}}$ & $12.13 \pm 0.11^{\mathrm{ab}}$ & $12.32 \pm 0.31^{\mathrm{ab}}$ & $13.05 \pm 0.02^{\mathrm{a}}$ \\
\hline Crude protein $(\%)$ & $40.03 \pm 1.01^{\mathrm{a}}$ & $39.97 \pm 0.51^{\mathrm{a}}$ & $39.84 \pm 0.41^{\mathrm{a}}$ & $40.22 \pm 0.49^{\mathrm{a}}$ & $40.39 \pm 0.41^{\mathrm{a}}$ & $39.92 \pm 0.60^{\mathrm{a}}$ \\
\hline Crude lipid (\%) & $8.22 \pm 0.21^{\mathrm{a}}$ & $7.63 \pm 0.04^{\mathrm{b}}$ & $8.71 \pm 0.11^{\mathrm{a}}$ & $9.01 \pm 0.32^{\mathrm{a}}$ & $8.92 \pm 0.03^{\mathrm{a}}$ & $9.04 \pm 0.23^{\mathrm{a}}$ \\
\hline Crude fibre (\%) & $6.14 \pm 0.01^{\mathrm{b}}$ & $6.52 \pm 0.12^{\mathrm{ab}}$ & $6.64 \pm 0.11^{\mathrm{a} b}$ & $6.88 \pm 0.02^{\mathrm{a}}$ & $6.32 \pm 0.14^{\mathrm{b}}$ & $7.31 \pm 0.31^{\mathrm{a}}$ \\
\hline Moisture (\%) & $8.42 \pm 0.31^{\mathrm{b}}$ & $9.36 \pm 0.23^{\mathrm{a}}$ & $9.42 \pm 0.11^{\mathrm{a}}$ & $8.58 \pm 0.13^{\mathrm{b}}$ & $8.39 \pm 0.21^{\mathrm{b}}$ & $9.22 \pm 0.02^{\mathrm{a}}$ \\
\hline Nitrogen-free extract (\%) & $25.63 \pm 0.51^{\mathrm{a}}$ & $24.83 \pm 0.25^{\mathrm{a}}$ & $24.65 \pm 0.43^{\mathrm{a}}$ & $23.90 \pm 0.12^{\mathrm{b}}$ & $23.66 \pm 0.31^{\mathrm{b}}$ & $21.46 \pm 0.21^{\mathrm{c}}$ \\
\hline
\end{tabular}

Mean values with different superscripts along the same row were significantly different $(p<0.05)$.

Table 4: Body composition of $C$. gariepinus fingerlings fed flamboyant leaf meal-based diets

\begin{tabular}{llllllll}
\hline $\begin{array}{l}\text { Proximate } \\
\text { parameters }\end{array}$ & $\begin{array}{l}\text { Initial } \\
\text { Pre-treatment } \\
\text { carcass values }\end{array}$ & $\begin{array}{l}\text { Diet 1 } \\
\text { (control) }\end{array}$ & Diet 2 & Diet 3 & Diet 4 & Diet 5 & Diet 6 \\
\hline Crude protein (\%) & $60.54 \pm 0.58^{\mathrm{d}}$ & $64.61 \pm 0.30^{\mathrm{c}}$ & $66.32 \pm 0.05^{\mathrm{b}}$ & $68.58 \pm 0.58^{\mathrm{a}}$ & $68.89 \pm 0.81^{\mathrm{a}}$ & $67.48 \pm 0.86^{\mathrm{b}}$ & $64.72 \pm 0.76^{\mathrm{c}}$ \\
Crude lipid (\%) & $6.84 \pm 0.17^{\mathrm{a}}$ & $6.87 \pm 0.34^{\mathrm{a}}$ & $6.49 \pm 0.16^{\mathrm{a}}$ & $6.64 \pm 0.17^{\mathrm{a}}$ & $5.84 \pm 0.54^{\mathrm{b}}$ & $6.33 \pm 0.36^{\mathrm{a}}$ & $6.34 \pm 0.42^{\mathrm{a}}$ \\
Ash (\%) & $5.22 \pm 0.02^{\mathrm{a}}$ & $5.71 \pm 0.11^{\mathrm{a}}$ & $5.41 \pm 0.01^{\mathrm{a}}$ & $4.24 \pm 0.12^{\mathrm{b}}$ & $4.27 \pm 0.01^{\mathrm{b}}$ & $5.59 \pm 0.02^{\mathrm{a}}$ & $6.10 \pm 0.01^{\mathrm{a}}$ \\
Nitrogen-free extract (\%) & $16.20 \pm 0.06^{\mathrm{a}}$ & $13.83 \pm 0.12^{\mathrm{c}}$ & $13.32 \pm 0.40^{\mathrm{c}}$ & $13.53 \pm 0.12^{\mathrm{c}}$ & $13.37 \pm 0.05^{\mathrm{c}}$ & $14.17 \pm 0.12^{\mathrm{b}}$ & $14.24 \pm 0.06^{\mathrm{b}}$ \\
Moisture (\%) & $11.22 \pm 0.32^{\mathrm{a}}$ & $8.98 \pm 0.13^{\mathrm{b}}$ & $8.46 \pm 0.41^{\mathrm{b}}$ & $7.01 \pm 0.14^{\mathrm{c}}$ & $7.63 \pm 0.30^{\mathrm{c}}$ & $6.43 \pm 0.11^{\mathrm{d}}$ & $8.60 \pm 0.23^{\mathrm{b}}$ \\
\hline
\end{tabular}

Mean values with different superscripts along the same row were significantly different $(p<0.05)$.

Table 5: Physico-chemical parameters of fish culture water in experimental aquaria

\begin{tabular}{lccc}
\hline Dietary treatments & $\mathrm{pH}$ & DO $(\mathrm{mg} / \mathrm{l})$ & Temperature $\left({ }^{\circ} \mathrm{C}\right)$ \\
Initial values & $7.35 \pm 0.15^{\mathrm{a}}$ & $6.43 \pm 0.01^{\mathrm{a}}$ & $26.15 \pm 0.20^{\mathrm{a}}$ \\
Treatment 1 $(0 \%$ SFLM) & $7.59 \pm 0.37^{\mathrm{a}}$ & $5.84 \pm 0.21^{\mathrm{a}}$ & $26.60 \pm 0.32^{\mathrm{a}}$ \\
Treatment 2 $(20 \%$ SFLM) & $7.65 \pm 0.25^{\mathrm{a}}$ & $6.39 \pm 0.37^{\mathrm{a}}$ & $27.23 \pm 0.15^{\mathrm{a}}$ \\
Treatment 3 (40\% SFLM) & $7.74 \pm 0.43^{\mathrm{a}}$ & $5.87 \pm 0.42^{\mathrm{a}}$ & $26.78 \pm 0.21^{\mathrm{a}}$ \\
Treatment 4 (60\% SFLM) & $7.47 \pm 0.16^{\mathrm{a}}$ & $6.41 \pm 0.17^{\mathrm{a}}$ & $26.49 \pm 0.07^{\mathrm{a}}$ \\
Treatment 5 (80\% SFLM) & $7.83 \pm 0.35^{\mathrm{a}}$ & $6.32 \pm 0.41^{\mathrm{a}}$ & $27.41 \pm 0.28^{\mathrm{a}}$ \\
Treatment 6 $(100 \%$ SFLM) & $7.71 \pm 0.04^{\mathrm{a}}$ & $5.95 \pm 0.32^{\mathrm{a}}$ & $27.53 \pm 0.20^{\mathrm{a}}$ \\
\hline
\end{tabular}

Mean values with similar superscripts along the same row were not significantly different $(p>0.05)$. 


\section{Growth and Feed Utilization of $C$. gariepinus Fingerlings Fed Graded Levels of Sundried Flamboyant Leaf Meal-Based Diets}

Table 6 shows the growth and feed utilization indices which exhibited significant $(p<0.05)$ variations in the fish exposed to the experimental diets. Acceptability of the experimental diets significantly $(p<0.05)$ increased in fish fed diets 1 to 3 beyond which it then assumed a reducing trend with increase in the substitution level of sundried flamboyant leaf meal. Mean weight gain (MWG) and specific growth rate (SGR) were highest (11.73 $\mathrm{g}$ and $2.13 \%$ day $^{-1}$, respectively) in fish fed diet 3 and lowest (9.06 $\mathrm{g}$ and $1.82 \%$ day $^{-1}$, respectively) in those fed diet 6 . MWG and SGR significantly $(p<0.05)$ increased in fish fed diets 1 to 3 beyond which they assumed a declining trend in those fed diets 4 to 6 . Values (0.451-0.514) recorded for the feed conversion ratio (FCR) showed significant $(p<0.05)$ variations across treatments, with fish fed diet 3 indicating efficient feed utilization. Values recorded for the protein intake (PI), protein efficiency ratio (PER) and percentage survival (PS) showed significant $(p<0.05)$ variations across treatments and fish fed with diet 3 had the highest values of these indices.

\section{DISCUSSION}

Result of proximate analysis showed that flamboyant leaf meal had high levels of crude protein $(24.72 \%)$ and nitrogen-free extract (40.86\%). According to Auta and Anwa (2007), a criterion for a feedstuff to be regarded as a potential protein source is that its crude protein level must exceed 20\%. This implies that flamboyant leaf meal has a considerable potential as a good source of protein for fish. The proximate composition of the experimental diets administered to C. gariepinus fingerlings in this study fell within the range expected to support ideal fish growth $(\mathrm{Li}$ et al., 2014). The lack of significant variations in the crude protein values indicated absence of bias while compounding the experimental diets. The values agreed with the acceptable range (28-39\%) for ideal catfish growth (Borgstorm, 1992) and also supported 39.98 to $40.01 \%$ reported by Adegbesan et al. (2018) for Aloe barbadensis leaf meal-based diets. Crude lipid values agreed with $10-20 \%$ lipid in fish diets which generally supports optimal growth rate without producing an excessively fatty carcass (Tibbetts and Lall, 2013). The values, however, exceeded 4.15-5.05\% documented by Dienye and Olumuji (2014) for Moringa oleifera leaf meal-based diets. Values of ash content were closely similar to $11.50-13.70 \%$ documented by Anyanwu et al. (2008) for Alchornia cordifolia leaf meal-based diets. The highest value of ash obtained in diet 6 could be attributed to its highest inclusion of sundried flamboyant leaf meal. The values of ash and crude fibre contents obtained in this study favourably aligned with $8-12 \%$ recommended for optimal fish growth (Condey, 2002), since higher ash and crude fiber contents generally reduce the digestibility of other feed ingredients in the diet and result in high waste output which may cause water pollution and poor growth. Values of moisture content observed in the experimental diets nearly corresponded to $7.31-9.81 \%$ obtained by Dienye and Olumuji (2014) for M. oleifera leaf meal-based diets while the values recorded for nitrogen-free extract, however, were lower than 34.83-36.61\% obtained by Dienye and Olumuji (2014). The variations between the observed proximate values in this study and other related studies could be due to the influence of environmental factors on the seeds (Akajiaku et al., 2014), morphological differences in plant species, processing methods and variations in ingredient combinations.

The fact that all experimental diets significantly increased the protein content of $C$. gariepinus fingerlings implied that there was enhanced protein synthesis and tissue formation as reported by Fountoulaki et al. (2003) and Yusuf et al. (2016) for gilthead bream (Sparus aurata) fingerlings and C. gariepinus juveniles respectively. Comparable trends of improved carcass crude protein were documented for $C$. gariepinus fingerlings fed $M$. oleifera leaf meal-based diets (60.03-62.47\%) (Dienye and Olumuji 2014) and Azadirachta indica

Table 6: Growth response and feed utilization of $C$. gariepinus fingerlings fed graded levels of sundried flamboyant leaf meal-based diets

\begin{tabular}{|c|c|c|c|c|c|c|}
\hline $\begin{array}{l}\text { Growth } \\
\text { Parameters }\end{array}$ & $\begin{array}{l}\text { Diet } 1 \\
\text { (control) }\end{array}$ & Diet 2 & Diet 3 & Diet 4 & Diet 5 & Diet 6 \\
\hline Initial mean weight $(\mathrm{g})$ & $5.12 \pm 0.10^{\mathrm{a}}$ & $5.11 \pm 0.21^{\mathrm{a}}$ & $5.11 \pm 0.18^{\mathrm{a}}$ & $5.10 \pm 0.30^{\mathrm{a}}$ & $5.10 \pm 0.14^{\mathrm{a}}$ & $5.12 \pm 0.05^{\mathrm{a}}$ \\
\hline Final mean weight (g) & $14.54 \pm 0.20^{\mathrm{b}}$ & $14.62 \pm 0.11^{\mathrm{b}}$ & $16.84 \pm 0.17^{\mathrm{a}}$ & $14.60 \pm 0.31^{\mathrm{b}}$ & $14.48 \pm 0.24^{\mathrm{bc}}$ & $14.18 \pm 0.41^{\mathrm{c}}$ \\
\hline Mean weight gain $(\mathrm{g})$ & $9.42 \pm 0.21^{\mathrm{b}}$ & $9.51 \pm 0.32^{\mathrm{b}}$ & $11.73 \pm 0.02^{\mathrm{a}}$ & $9.50 \pm 0.41^{\mathrm{b}}$ & $9.38 \pm 0.33^{\mathrm{b}}$ & $9.06 \pm 0.14^{\mathrm{b}}$ \\
\hline Percentage weight gain (\%) & $183.98 \pm 0.12^{\mathrm{c}}$ & $186.11 \pm 0.21^{\mathrm{b}}$ & $229.55 \pm 0.13^{\mathrm{a}}$ & $185.91 \pm 0.06^{\mathrm{b}}$ & $183.56 \pm 0.12^{\mathrm{c}}$ & $176.95 \pm 0.03^{\mathrm{d}}$ \\
\hline Specific growth rate $(\% /$ day $)$ & $1.86 \pm 0.11^{\mathrm{b}}$ & $1.88 \pm 0.04^{\mathrm{b}}$ & $2.13 \pm 0.23^{\mathrm{a}}$ & $1.88 \pm 0.21^{\mathrm{b}}$ & $1.86 \pm 0.10^{\mathrm{b}}$ & $1.82 \pm 0.12^{\mathrm{c}}$ \\
\hline Total feed intake $(\mathrm{g})$ & $189.58 \pm 1.23^{\mathrm{b}}$ & $190.35 \pm 0.54^{\mathrm{b}}$ & $211.66 \pm 0.61^{\mathrm{a}}$ & $190.26 \pm 0.45^{\mathrm{b}}$ & $189.01 \pm 0.58^{\mathrm{b}}$ & $186.13 \pm 0.60^{\mathrm{c}}$ \\
\hline Mean feed intake (g) & $4.74 \pm 0.01^{\mathrm{b}}$ & $4.76 \pm 0.13^{\mathrm{b}}$ & $5.29 \pm 0.31^{\mathrm{a}}$ & $4.76 \pm 0.21^{\mathrm{b}}$ & $4.73 \pm 0.01^{\mathrm{b}}$ & $4.65 \pm 0.12^{\mathrm{c}}$ \\
\hline Feed conversion ratio & $0.503 \pm 0.10^{\mathrm{b}}$ & $0.500 \pm 0.21^{\mathrm{b}}$ & $0.451 \pm 0.11^{\mathrm{c}}$ & $0.501 \pm 0.12^{\mathrm{b}}$ & $0.504 \pm 0.12^{\mathrm{b}}$ & $0.514 \pm 0.03^{\mathrm{a}}$ \\
\hline Protein intake & $1.89 \pm 0.03^{\mathrm{b}}$ & $1.90 \pm 0.20^{\mathrm{b}}$ & $2.11 \pm 0.21^{\mathrm{a}}$ & $1.91 \pm 0.22^{\mathrm{b}}$ & $1.91 \pm 0.14^{\mathrm{b}}$ & $1.86 \pm 0.31^{\mathrm{b}}$ \\
\hline Protein efficiency ratio & $4.96 \pm 0.43^{\mathrm{b}}$ & $5.00 \pm 0.32^{\mathrm{b}}$ & $5.57 \pm 0.15^{\mathrm{a}}$ & $4.96 \pm 0.51^{b}$ & $4.91 \pm 0.18^{b}$ & $4.88 \pm 0.41^{\mathrm{b}}$ \\
\hline Nitrogen metabolism & $302.21 \pm 0.58^{b}$ & $303.29 \pm 1.15^{\mathrm{b}}$ & $337.42 \pm 0.65^{\mathrm{a}}$ & $303.14 \pm 1.25^{\mathrm{b}}$ & $301.29 \pm 1.43^{\mathrm{b}}$ & $296.68 \pm 1.06^{\mathrm{c}}$ \\
\hline Percentage survival (\%) & $75.00 \pm 1.01^{\mathrm{b}}$ & $77.50 \pm 0.61^{\mathrm{b}}$ & $82.50 \pm 0.54^{\mathrm{a}}$ & $77.50 \pm 1.23^{\mathrm{b}}$ & $75.00 \pm 1.02^{\mathrm{b}}$ & $72.50 \pm 0.51^{\mathrm{c}}$ \\
\hline
\end{tabular}

Mean values with different superscripts along the same row were significantly different $(p<0.05)$. 
leaf meal-based diets (66.12-67.86\%) (Anyanwu et al., 2015). Crude lipid values closely harmonized with $5.84-6.31 \%$ and $4.10-7.63 \%$ reported for $C$. gariepinus fingerlings fed $M$. oleifera leaf mealbased diets (Dienye and Olumuji 2014) and $A$. indica leaf meal-based diets (Anyanwu et al., 2015) respectively. Ash content values were much below $16.90-18.32 \%$ reported by Afe and Omosowone (2019) for C. gariepinus fingerlings fed with Acacia auriculiformis leaf meal-based diets. Values of moisture content contradicted those obtained by Afe and Omosowone (2019) in C. gariepinus fingerling which showed no significant variation. Values of nitrogen-free extract harmonized with those reported by Afe and Omosowone (2019) which followed a reducing trend in $C$. gariepinus fingerlings. Variations in fish body composition between this study and other studies could be due to interspecies' genetic variations, different plantbased ingredients and processing techniques used as well as influence of environmental factors/culture conditions. The values of the physico-chemical parameters of water quality measured in the experimental units were within the ideal range of values recommended for successful culture of tropical warm-water fishes such as $C$. gariepinus. These values corroborated those reported by Idowu et al. (2020) on juvenile $O$. niloticus treated with graded Kigelia africana stem bark aqueous extract. Similar findings were documented by Tolan and Sherif (2007), Musa et al. (2013) and Samkelisiwe and Ngonidzashe (2014) in related laboratory-based fish nutritional studies using different plant parts as dietary supplements. Water temperature, dissolved oxygen and $\mathrm{pH}$ are among important parameters in fish culture which significantly affect feed and/or protein intake and growth either positively or negatively. The result also harmonized with that of Okechi (2004) who reported $25-30^{\circ} \mathrm{C}$ as optimum temperature for warm-water fish culture. These results indicated that processed flamboyant leaves can be profitably used in aquaculture as they did not impair the ideal water quality conditions.

Incorporation of sundried flamboyant leaf meal in the diets of $C$. gariepinus fingerlings in this study resulted in considerable improvement in their growth and feed utilization. Similar observations have been reported on $O$. niloticus and Heterobranchus bidorsalis fingerlings fed with differently processed flamboyant seed meal (Balogun et al., 2004; Bake et al., 2013, 2014; Oyegbile et al., 2017). Fish fed with diet 3 had the best growth and feed utilization indices which obviously indicated optimal diet utilization that was not feasible at higher substitution levels as growth progressively declined with increasing substitution levels. The higher values of MWG and SGR in fish fed with diet 3 clearly suggested that they optimally converted feed to flesh when compared with those fed with the other diets. The slightly lower growth response by fish fed with diet 6 is attributed to reduced palatability of the diet which probably resulted from low feed intake. The SGR values obtained in this study suggested superior growth response compared to $0.25-0.59 \%$ day $^{-1}$ reported by Adesina and Ikuyeju (2019) for C. gariepinus fingerlings fed pawpaw leaf mealbased diets and $0.44-1.81 \%$ day $^{-1}$ observed by Anyanwu et al. (2008) for hybrid Heteroclarias (H. bidorsalis $\times C$. gariepinus) fingerlings fed $A$. cordifolia leaf meal-based diets.

Lower feed conversion ratio (FCR) indicates better feed utilization by the fish. According to De Silva (2001), an ideal feed conversion ratio ranges between 1.2 and 1.8 for fish fed carefully prepared diets and FCR values in the present study were slightly below this range. In addition, the present FCR values suggested better feed utilization compared to 1.71-1.85 reported for Heteroclarias fingerlings fed cassava root meal-based diets (Abu et al., 2010) and 1.31-3.30 documented by Dienye and Olumuji (2014) for C. gariepinus fingerlings fed $M$. oleifera leaf meal-based diets. The ability of an organism to effectively absorb and utilize dietary nutrients, especially protein, will positively enhance its growth performance. This was justified by the best protein intake, protein efficiency ratio (PER) and growth performance indices recorded for fish fed with diet 3 . The current protein intake values indicated better dietary protein assimilation

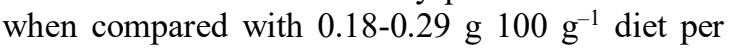
fish reported by Anyanwu et al. (2008) for Heteroclarias fingerlings as well as $0.84-1.33 \mathrm{~g}$ $100 \mathrm{~g}^{-1}$ diet per fish observed by Adesina and Ikuyeju (2019) for C. gariepinus fingerlings. Similarly, the PER values obtained in this study suggested superior dietary protein utilization compared to 1.54-1.98 reported for Heteroclarias fingerlings fed cassava root meal-based diets (Abu et al., 2010) and 1.67-2.58 recorded by Oyelere et al. (2016) for C. gariepinus fingerlings. According to Davis (2004), protein efficiency ratio is a measure of how effectively the protein sources in a diet can supply the needed essential amino acids in the fish fed with such a diet. The observed fish survival rate in this study corresponded to 76.26-87.45\% reported by $\mathrm{Abu}$ et al. (2010) for Heteroclarias fingerlings and also indicated better survival in comparison with $48.00 \%$ to $86.00 \%$ recorded by Anyanwu et al. (2015) for C. gariepinus fingerlings. Such high level of survival indicated that feeding $C$. gariepinus fingerlings with sundried flamboyant leaf meal did not cause serious fish mortality. Besides, it reflected adequate acceptability of the experimental diets by fish which could be attributed to good handling, adequate water quality management, proper feed 
processing to substantially reduce anti-nutrients and suitability of sundried flamboyant leaf meal inclusion in the diet of $C$. gariepinus. However, higher survival values $(90.00-96.67 \%$ and $93.33-$ $100.00 \%$ ) have been reported for $C$. gariepinus fingerlings fed A. lebbeck (Oyelere et al. 2016) and M. oleifera (Dienye and Olumuji, 2014) leaf mealbased diets, respectively.

\section{CONCLUSION}

The results from this study showed that substitution of sundried flamboyant leaf meal as an alternative protein source for groundnut cake in $C$. gariepinus fingerlings' diet above $40 \%$ caused reducing growth and decreased feed utilization. The study, therefore, indicated that processed flamboyant leaf meal could efficiently replace groundnut cake up to $40 \%$ in the diets of C. gariepinus without obvious deleterious effects on its growth response, feed utilization and survival. The acceptance of the experimental diets in this study as reflected by the feed utilization indices has established the flexibility of C. gariepinus fingerlings to efficiently utilize a wide range of unconventional feed ingredients. Other processing methods are recommended with a view to increasing the utilization of flamboyant leaf meal which has a considerable potential in reducing the cost of production of fish feed and thereby maximize aquaculture profitability.

\section{CONFLICT OF INTERESTS}

The authors have declared no conflict of interests.

\section{ACKNOWLEDGEMENT}

The authors gratefully acknowledge the support of the Chief Technologist, Mr. M.O. Oguntokun, and his colleagues in the Department of Animal Production and Health, Federal University of Technology, Akure, Nigeria for technical assistance during chemical analyses of experimental diets and fish. The painstaking and critical evaluation of the paper by the reviewers as well as the timely and thorough handling of the manuscript by the Editorial Board of Agro-Science is highly commendable.

\section{REFERENCES}

Abu O.M.G., Gabriel, U.U. and Akinrotimi, O.A. (2010). Performance and survival of hybrid catfish (Heteroclarias) fed with whole cassava root meal as a replacement for maize. Agro-Science, 9 (3), 176-183

Adegbesan S.I., Obasa S.O. and Abdulraheem I. (2018). Growth performance, haematology and histopathology of African catfish (Clarias gariepinus) fed varying levels of Aloe barbadensis leaves. Journal of Fisheries, 6 (1), 553-562

Adesina S.A. and Ikuyeju M.F. (2019). Effects of replacing soybean meal with graded levels of pawpaw (Carica papaya) leaf meal in the diets of Clarias gariepinus fingerlings. Coast Journal of Faculty of Science, 1 (1), 130-142
Afe O.E. and Omosowone O.O. (2019). Growth and feed utilization in Clarias gariepinus fingerlings fed on Acacia auriculiformis leaf-supplemented diets. International Journal of Fisheries \& Aquaculture, 11 (3), 55-61

Akajiaku L.O., Nwosu J.N., Onuegbu N.C., Njoku N.E. and Egbeneke C.O. (2014). Proximate, mineral and anti-nutrient composition of processed (soaked and roasted) tamarind (Tamarindus indica) seed nut. Current Research Journal of Nutrition \& Food Science, 2 (3), 136-145

Ali A., Al-Asgah N.A., Al-Ogaily S.M. and Ali S. (2003). Effect of feeding different levels of alfalfa meal on the growth performance and body composition of Nile tilapia (Oreochromis niloticus) fingerlings. Asian Fisheries Society, 16, 1-2

Anyanwu D.C., Offor J.I. and Nkulo U.U. (2015). Product quality assessment of Clarias gariepinus fed on varying dietary levels of Azadirachta indica leaf meal. American Journal of Experimental Agriculture, 9 (6), 1-6

Anyanwu D.C., Udedibie A.B.I., Osuigwe D.I. and Esonu B.O. (2008). Growth and nutrient utilization of Heteroclarias (H. bidorsalis $x$ C. gariepinus) fed dietary levels of Alchornia cordifolia leaf meal. Journal of Agriculture \& Social Research, 8 (2), 179-185

AOAC (2011). Official Methods of Analysis (18th ed.) Association of Official Analytical Chemists, Arlington, Virginia, p. 542

Auta J. and Anwa E.P. (2007). Preliminary studies on Albizzia lebbeck seeds: proximate analysis and phytochemical screening. Research Journal of Biological Sciences, 2 (1), 33-35

Bake G.G., Endo M., Akimoto A. and Takeuchi T. (2009). Evaluation of recycled food waste as a partial replacement of fishmeal in the diets for first feeding Nile tilapia Oreochromis niloticus. Fisheries Science, 75, $1275-1283$

Bake G.G., Adejumo T.M. and Sadiku S.O.E. (2013). Growth performance and nutrient utilization of Nile Tilapia (Oreochromis niloticus) fed toasted flamboyant (Delonix regia) seed meal. Continental Journal of Agricultural Science, 7 (1), 1-10

Bake G.G., Martins E.I. and Sadiku S.O.E. (2014). Nutritional evaluation of varying levels of cooked flamboyant (Delonix regia) seed meal on the growth performance and body composition of Nile Tilapia (Oreochromis niloticus) fingerlings. Agriculture, Forestry \& Fisheries, 3 (4), 233-239

Balogun, J.K., Abdullahi, S.A., Auta, J. and Ogunlade, I. (2004). Feed conversion, protein efficiency, digestibility and growth performance of Oreochromis niloticus fed Delonix regia meal. $19^{\text {th }}$ Annual Conference Proceedings of the Fisheries Society of Nigeria (FISON). pp. 823-831

Borgstorm G. (1992). Fish as Food/Feed. New York Academic Press, 1, 477

Burel C., Boujard T., Tulli F. and Kaushik S.J. (2000). Digestibility of extruded peas, extruded lupin, and rapeseed meal in rainbow trout (Oncorhynchus mykiss) and turbot (Psetta maxima). Aquaculture, 188, 285-298

Condey R.E. (2002). Ingestion-limited growth for aquatic animals. The case for blackman kinetics. Canadian Journal of Fishery \& Aquatic Resources, 23, 112-120 
Davis A.R. (2004). Correlation of plasma IGF-I concentrations and growth rate in aquacultured finfish: a tool for assessing the potential of new diets. Aquaculture, 236, 583-592

De Silva S.S. (2001). Performance of Oreochromis niloticus fry maintained on mixed feeding schedules of different protein levels. Aquaculture \& Fisheries, 16, 621-633

Dienye H.E. and Olumuji O.K. (2014). Growth performance and haematological responses of African mud catfish Clarias gariepinus fed dietary levels of Moringa oleifera leaf meal. Net Journal of Agricultural Science, 2 (2), 79-88

El-Saidy D.M.S.D. and Gaber M.M.A. (2004). Use of cottonseed meal supplemented with iron for detoxification of gossypol as a total replacement of fish meal in Nile tilapia (Oreochromis niloticus L.) diets. Aquaculture Research, 35, 859-865

Fasakin E.A., Balogun A.M. and Fasuru B.E. (1999). Use of duckweed (Spirodela polyrrhiza L. Schleiden) as a protein feedstuff in practical diets for tilapia, Oreochromis niloticus L. Aquaculture Research, 30, 313-318

Fountoulaki E., Alexis M.N., Nengas I. and Venon B. (2003). Effects of dietary arachidonic acid (20:4n-6) on growth, body composition and tissue fatty acid profile of gilthead bream (Sparus aurata L.) fingerlings. Aquaculture, 225, 309-323

Francis G., Makkar H.P.S. and Becker K. (2001). Antinutritional factors present in plant derived alternate fish feed ingredients and their effects in fish. Aquaculture, 199 (3 \& 4), 197-227

Grant G., Moore I.J., Mckenzie N.H., et al. (1991). A survey of haemaglutination properties of several tropical seeds. Livestock Research for Rural Development, 3,1-7

Idowu A.A., Popoola O.C., Alani J.O., Ipadeola A. and Nwekoyo V.E. (2020). Toxicity effect of Kigelia africana aqueous extract on the haematology and histopathology of juvenile Nile Tilapia (Oreochromis niloticus). Agro-Science, 19 (1), 37- 42. DOI: https://dx.doi.org/10.4314/as.v19i1.6

Theanacho S.C., Ogunji J.O., Ogueji E.O., et al. (2017). Comparative assessment of ampicillin antibiotic and ginger (Zingiber officinale) effects on growth, haematology and biochemical enzymes of Clarias gariepinus juveniles. Journal of Pharmacognosy \& Phytochemistry. 6 (3), 761-767

Koumi A.R., Atse B.C. and Kouame L.P. (2009). Utilization of soybean protein as an alternative protein source in Oreochromis niloticus diet: growth performance, feed utilization, proximate composition and organoleptic characteristics. African Journal of Biotechnology, 8 (1), 91-97

Li X.F., Wang Y., Liu W.B., Jiang G.Z. and Zhu J. (2014). Effects of dietary carbohydrate/lipid ratios on growth performance, body composition and glucose metabolism of fingerling blunt snout bream (Megalobrama amblycephala). Aquaculture Nutrition, 2, 1-12

Musa S.M., Aura C.M., Ogello E.O., Omondi R., CharoKarisa H. and Munguti J.M. (2013). Haematological response of African catfish (Clarias gariepinus Burchell 1822) fingerlings exposed to different concentrations of tobacco (Nicotiana tobaccum) leaf dust. ISRN Zoology, 2013, 1-7
Nwanna L.C. (2003). Replacement of fish meal with chemically preserved shrimp head meal in the diets of African catfish. Pakistan Journal of Nutrition, 2, 339-345

Okechi J.K. (2004). Profitability assessment: A case study of African catfish (Clarias gariepinus) farming in the Lake Victoria Basin, Kenya. Kenya Marine and Fisheries Research Institute (KMFRI), Kisumu Research Centre, Final Project. pp. 1-56

Ovie S.O. and Ovie S.I. (2007). The effect of replacing fishmeal with $10 \%$ of groundnut cake in the diets of Heterobranchus longifilis on its growth, food conversion and survival. Journal of Applied Science \& Environmental Management, 11(3), 87-90

Oyegbile B., Abdullahi B.A. and Yola I.A. (2017). Haematological profile of Heterobranchus bidorsalis fingerlings fed processed Delonix regia seeds at different inclusion levels of diets. International Journal of Fisheries \& Aquaculture, 9 (8), 81-85

Oyelere E.A., Balogun J.K. and Abubakar B.Y. (2016). Growth and nutrient utilization of African catfish (Clarias gariepinus Burchell, 1822) fed varying levels of Albizia lebbeck (Benth) leaf meal. Agrosearch, 16 (1), 15-24

Purseglove J.W. (1994). Tropical crops: Dicotyledons. Longman, London, U.K., p. 122

Samkelisiwe N.H. and Ngonidzashe A.M. (2014). Replacing fishmeal with kikuyu grass and moringa leaves: effects on growth, protein digestibility, histological and haematological parameters in Clarias gariepinus. Turkish Journal of Fisheries \& Aquatic Sciences, 14, 795-806

Soltan M.A. and El-Laithy S.M. (2008). Effects of probiotics and some spices as feed additives on the performance and behaviour of the Nile Tilapia, Oreochromis niloticus. Egyptian Journal of Aquatic Biology \& Fishery, 12 (2), 63-80

Tacon A.G.J. (1993). Feed ingredients for warm water fish. Fishmeal and other processed feedstuffs. FAO Fish. Circ. No. 856, FAO, Rome, Italy, pp. 64

Tibbetts S.M. and Lall S.P. (2013). Effect of dietary inclusion of Atlantic snow crab, Chionoecetes opilio and Northern pink shrimp (Pandalis borealis) processing by-products on nutrient digestibility by juvenile haddock (Melanogrammus aeglefinus). Animal Feed Science \& Technology, 182 (1-4), 126-130

Tolan A.E. and Sherif A.H. (2007). Effect of some growth promoters on growth performance of Nile Tilapia (Oreochromis niloticus) fingerlings. Arabic Journal of Aquaculture, 2(1), 89-104

Yusuf A., Umar R., Micah D.A. and Akpotu J.O. (2016). Growth response and feed utilization of Clarias gariepinus (Burchell, 1822) juveniles fed graded levels of boiled Senna obtusifolia L. seed meal as a replacement for soybean meal. Journal of Advanced Veterinary \& Animal Research, 3 (4), 345-352

Zar J.H. (1996). Biostatistical Analysis ( $3^{\text {rd }}$ ed.). Prentice-Hall International Inc., Upper Saddle River, New Jersey, US. pp. 282-283 